\title{
INSTYTUT HISTORII UNIWERSYTETU W BIAŁYMSTOKU W LATACH 1968-1998
}

W 1998 roku Instytut Historii Uniwersytetu w Białymstoku obchodził swoje trzydziestolecie. Jego dzieje zaczynają się jednak w momencie powstania Filii Uniwersytetu Warszawskiego, która została powołana zarządzeniem ministerialnym z 15 lipca 1968 r. Przewidziano w niej także Wydział Humanistyczny, początkowo m.in. z trzyletnimi wyższymi studiami zawodowymi na kierunku: filologia polska $z$ historią. Wobec braku na miejscu dostatecznej liczby wykładowców (kadry) zapraszano profesorów z Instytutu Historycznego UW, w tym Aleksandra Gieysztora i Stanisława Herbsta. Od 1969 r. stały kontakt $z$ nową placówką akademicką nawiązał doc. dr hab. Andrzej Wyrobisz i przejął on opiekę nad zajęciami z historii, oraz kierownictwo Zakładu. W 1971 r. przeprowadzono pierwszy nabór na trzyletnie studia historii z przysposobieniem obronnym, w 1973 r. uruchomiono studia magisterskie historii (wówczas kurs 4-letni). W roku akademickim 1973/1974 studiowało historię łącznie 113 studentów dziennych i 56 zaocznych. Wzrastała i liczba pracowników w Zakładzie Historii. Pierwszym stałym pracownikiem był dr Adam Dobroński (1972 r.), a w 1974 r. przy jęto liczną grupę pracowników samodzielnych (prof. Andrzej Wyczański, doc. dr hab. Ewa Wipszycka-Bravo, docenci kontraktowi: Teresa Monasterska, Mieczysław Wrzosek, następnie Michał Gnatowski). W roku akademickim 1973/1974 realizowano już w Zakładzie Historii 2700 godzin dydaktycznych. Dawało to szansę przyjmowania asystentów, w tym również własnych wychowanków (jako pierwsi podjęli pracę Józef Maroszek i Jan Jerzy Milewski).

W 1975 r. kierownictwo Zakładu Historii przejęła doc. dr hab. Elżbieta Kaczyńska. Zaczęto zabiegać o utworzenie nowych specjalizacji (bi- 
bliotekarstwo, archiwistyka). Dynamicznie zwiększała się liczba pracowników w związku z koniecznością otwierania nowych seminariów magisterskich i obsadzania zajęć specjalistycznych na wyższych latach studiów. Nadal jednak dominowali wykładowcy zatrudnieni etatowo w Warszawie, a stałym pracownikiem został od 1 października 1977 r. doc. dr hab. Stanisław Alexandrowicz. W dziesiątym roku istnienia Filii na kierunku historia mieliśmy 173 studentów dziennych i 93 zaocznych. W 1977 r. dyplomy magisterskie otrzymało pierwszych 48 historyków (26 na studiach dziennych i 22 na zaocznych). Wyraźnie wzrosła aktywność naukowa pracowników Zakładu, a kilkoro $z$ nich znalazło się w składzie władz akademickich. Regułą stały się przyjazdy do Filii wybitnych historyków na gościnne wykłady i spotkania warsztatowe. Kłopotów przysparzały skromne warunki lokalowe, co utrudniało także powiększanie zasobów bibliotecznych. Korzystano natomiast w szerokim zakresie ze staży i urlopów naukowych, nawiązywano kontakty zagraniczne. Dobrze pracowało Studenckie Koło Naukowe, wzbogacono programy objazdów naukowych.

Prof. A. Wyrobisz z grupa współpracowników od 1 września 1979 r. przystąpił do organizowania Instytutu Historii i 1 lutego 1980 r. został jego pierwszym dyrektorem. Instytut liczył juz 10 samodzielnych pracowników naukowych (w tym $4 \mathrm{z}$ UW i jeden $\mathrm{z}$ PAN na 1/2 etatu), 8 adiunktów, 11 asystentów i stażystów. Ponadto 4 osoby przebywały na studiach doktoranckich. Utworzono Radę Naukową z udziałem m.in. prof. prof. Andrzeja Garlickiego, Antoniego Mączaka (przewodniczący) i Benedykta Zientary. Instytut podzielił się na cztery Zakłady: historii starożytnej i średniowiecznej (kierownik doc. S. Alexandrowicz), historii nowożytnej XVI-XVIII w. (prof. A. Wyrobisz), historii najnowszej XIX-XX w. (doc. T. Monasterska), historii Polski Ludowej i świata współczesnego (doc. M. Gnatowski). Imponująco wypadł ogólnopolski debiut naukowy IH FUW w postaci sesji naukowej „Polska czasów saskich” (21-24 IV 1980 r.).

Nadchodziły miesiące niepokojów i nadziei. We wrześniu 1980 r. pracownicy naukowo-dydaktyczni Instytutu powitali z radością zmiany dokonujące się w ruchu związkowym, opowiedzieli się m.in. za weryfikacją treści nauczania przedmiotów ideologicznych i odejściem od tajnego systemu opiniowania w uczelniach. W opinii wielu, w tym i władz białostockich, Instytut stał się siedliskiem „niebezpiecznych nowinek”, miejscem przenoszenia programów i postulatów $z$ akademickiego środowiska warszawskiego. W czerwcu $1981 \mathrm{r}$. dyrektorem został wybrany dr hab. A. Dobroński, a od października wprowadzono nowy program studiów. Zaszły dość istotne zmiany w obsadzie personalnej; pracę na pół etatu podjęli m.in. docenci Andrzej Paczkowski 
i Wiesław Władyka. Normalny tok pracy przerwał stan wojenny, zawieszono przejściowo zajęcia, rozpoczęły się szykany wobec niektórych pracowników (ich kulminacja to wnioski o zwolnienia sformułowane w trakcie przeglądu kadrowego, ale zablokowane w UW) i studentów (aresztowania, proces). W Instytucie panowała nadal „daleko posunięta jedność poglądów na zasadnicze kwestie, wzajemna życzliwość i powaga". Zastanawiano się nad możliwością jeszcze ściślejszego powiązania z Insty tutem Historycznym UW, szczególnie $\mathrm{w}$ sprawach dydaktycznych i naukowych. Zgłoszono zarazem wnioski o otwarcie studiów podyplomowych i utworzono zespół do opracowania dziejów miasta Białegostoku, prowadzono studium wiedzy o historii regionu północno-wschodniego (29 wykładów). Powracała sprawa przenosin do nowego budynku.

W marcu 1983 r. zaszła konieczność dokonania zmiany na stanowisku dziekana Wydziału Humanistycznego, więc dyrektorem IH FUW ponownie został prof. A. Wyrobisz, a na czele Rady Naukowej stanęła prof. E. Wipszycka. Uznano, że „pomimo wielu trudności i w nieprzychylnej często atmosferze praca dydaktyczna i naukowa przebiega normalnie". W styczniu 1984 r. opracowany został wniosek o powołanie Pracowni Badań Regionalnych i w październiku podjęła ona pracę (kierował nią prof. S. Alexandrowicz). W $1985 \mathrm{r}$. Instytut zatrudniał na własnych etatach 33 pracowników dydaktycznych, którzy realizowali 5360 godzin. Na kilkunastu seminariach magisterskich stopnie magistrów uzyskało do tego roku 293 osoby. Eącznie w czerwcu 1985 r. wśród 38 pracowników naukowych IH FUW znajdowało się 2 profesorów, 7 docentów, 16 doktorów, 12 magistrów. Takie proporcje świadczyły o tworzeniu się miejscowego środowiska historycznego.

Rozwój Instytutu przebiegał już w spokojniejszej atmosferze w drugiej połowie lat osiemdziesiątych. Instytutem od roku akademickiego 1984/85 kierował prof. A. Wyczański, a Radą Naukową prof. E. Wipszycka (do 1988 r.) i przybyły z Uniwersytetu Jagiellońskiego prof. Władysław A. Serczyk. Wprowadzono istotne zmiany programowe i w 1988 r. dokonano rekonstrukcji Zakładów, nadając im obowiązujące aktualnie nazwy. Upowszechnił się zwyczaj tzw. wykładów równoległych, przybyło konwersatoriów. Na pierwsze lata studiów dziennych przy jmowano coraz więcej osób, a ponadto pracownicy IH prowadzili zajęcia $z$ historii na wielu innych kierunkach studiów. Zmniejszyła się natomiast nieco liczebność studentów zaocznych, zmalała przeciętna ich wieku. W tym okresie Instytut wyróżnial się w Filii pod względem rozwoju naukowego własnej kadry. W marcu $1991 \mathrm{r}$. było w nim 9 profesorów, 13 adiunktów, jeden starszy wykładowca i 10 asystentów. In- 
stytutem kierował prof. Adam Manikowski, zaś przewodnictwo Rady Naukowej sprawował prof. A. Wyczański. W 1993 r. Instytut Historii uzyskał prawo nadawania stopnia naukowego doktora i do tej pory wypromowal 2 doktorów.

Za wcześnie jeszcze na ocenę lat ostatnich. Z całą pewnością przybywało szybko publikacji, a wizytówką Instytutu stały się „Studia Podlaskie”. Zarazem zaznaczył się odpływ pracowników samodzielnych $z$ długim stażem pracy w Instytucie. Ich miejsce zajmują nowi (prof. Barbara Stępniewska-Holzer, prof. Hanna Zaremska, prof. Marian Leczyk, a ostatnio prof. Albertyna Szczudłowska-Dembska).

Na uwagę i przypomnienie zasługują także osoby, które śmierć zabrała z naszego grona: prof. dr hab. Andrzej Woltanowski, uznany specjalista okresu stanisławowskiego oraz dziejów Polaków na Syberii w XIX w., i dr Teresa Monasterska, przez wiele lat zajmująca się dziejami partii politycznych II Rzeczypospolitej.

Od 1994 roku Instytutem kieruje prof. dr hab. Barbara Stępniewska-Holzer, a wicedyrektorami są: dr hab. Cezary Kuklo - ds. studiów dziennych i wieczorowych oraz dr Włodzimierz Jarmolik - ds. studiów zaocznych i podyplomowych. Przewodniczącym Rady Naukowej pozostal prof. A. Wyczański.

Ostatnie trzy la ta charakteryzowały się, co także warto podkreślić, szybkim uzyskiwaniem habilitacji przez grono białostockich doktorów - Hannę Konopkę, Halinę Parafianowicz, Jerzego Urwanowicza, Antoniego Mironowicza, Cezarego Kuklę. Liczba przewodów habilitacyjnych, sądząc z zapowiedzi wydawniczych, nie powinna maleć, albowiem w ciągu najbliższych paru miesięcy ukażą się drukiem następne 2-3 rozprawy.

Wraz z uzyskaniem przez Filię statusu samodzielnego Uniwersytetu w Białymstoku w roku 1997, rozpoczął się nowy rozdział w działalności Instytutu.

W chwili obecnej (1998/99) w Instytucie pracuje 8 profesorów tytularnych, 10 profesorów uczelni, 2 doktorów habilitowanych, 7 adiunktów, 4 starszych wykładowców i 15 asystentów. Trzydziesty pierwszy rok studiów historycznych zainaugurowało 323 studentów dziennych, 418 zaocznych i 118 wieczorowych.

W Instytucie Historii prowadzone jest 18 seminariów magisterskich, kontynuowane są też w ramach Instytutu seminaria doktorskie: jedno prowadzone przez prof. A. Wyczańskiego, drugie łącznie prowadzone przez prof. prof. A. Dobrońskiego, M. Gnatowskiego i M. Wrzoska.

Insty tut prowadzi kształcenie na 5-letnich magisterskich studiach histo- 
rycznych w następu jących formach: studia stacjonarne, wieczorowe i zaoczne oraz na 2-letnich studiach podyplomowych z podziałem na absolwentów historii i absolwentów innych kierunków.

Kierunki badań uprawianych w ostatnich kilkunastu latach w Instytucie Historii można by podzielić na trzy lub cztery grupy.

Szczególną, gdyż pierwszoplanową pozycję zajmują najszerzej zakrojone studia nad dziejami regionu i ziem północno-wschodnich Polski oraz krajów ościennych ujmowane w długiej perspektywie od starożytności po współczesność. Historią Podlasia, Wielkiego Księstwa Litewskiego, Białorusi w okresie przedrozbiorowym zajmu ją się od lat prof. prof. S. Alexandrowicz, A. Mironowicz, J. Urwanowicz, dr dr A. Czapiuk, E. Dubas-Urwanowicz, W. Jarmolik, J. Maroszek. Swoje zainteresowania koncentrują oni wokół problematyki struktur społecznych i gospodarczych miast i miasteczek $z$ uwzględnieniem ich podstaw prawnych oraz problemu folwarku i gospodarki chłopskiej. Należałoby wspomnieć również o badaniach nad organizacją i duchowieństwie Kościoła katolickiego i prawosławnego, a także nad funkcjonowaniem i znaczeniem instytucji życia politycznego społeczeństwa staropolskiego jak sejmy, sejmiki czy konfederacje wojskowe.

Rosnący $\mathrm{z}$ roku na rok dorobek $\mathrm{w}$ tej dziedzinie pozwolił już $\mathrm{w}$ chwili obecnej zaprojektować na najbliższe kilka lat pierwszą oryginalną próbę ich podsumowania w postaci oddzielnych tomów prezentu jących historię miasta Białegostoku oraz dzieje i rolę Podlasia do końca Rzeczypospolitej szlacheckiej.

Dziejami tych terenów w okresie rozbiorów zajmują się prof. prof. A. Dobroński, B. Stępniewska-Holzer, dr J. Godlewski. Zwracają uwagę nowocześnie ujmowane studia nad uwarstwieniem społecznym i kondycją gospodarczą ziemiaństwa w tzw. "guberniach zachodnich”.

Z kolei studia prof. M. Gnatowskiego, dr dr J. J. Milewskiego, A. Miśkiewicza, E. Pankiewicz przybliżyły stosunki wewnętrzne (np. postawy i poglądy polityczne ludności polskiej i mniejszości narodowych, uwarunkowania działalności partii Drugiej Rzeczypospolitej) i wydarzenia polityczne (okupację sowiecką i niemiecką, ruch oporu, kształtowanie się polskiego państwa podziemnego) w regionie białostockim i na ziemiach należących obecnie do północno-wschodnich sąsiadów Polski w okresie międzywojennym i II wojny światowej.

Drugą ważną specjalizacją białostockiego środowiska naukowego stanowią badania nad dziejami powszechnymi. Prof. W. A. Serczyk do jesieni 1998 roku realizował szeroko zakrojone badania nad dziejami społeczno-politycznymi i kulturą Ukrainy i Rosji, prof. S. Meller (obecnie urlopowany 
w związku z pełnieniem funkcji ambasadora RP we Francji) zajmuje się wielkim problemem jaki stanowi rewolucja francuska 1789 r. z uwzględnieniem jej podstawowych problemów ustrojowych i rewolucji kulturalnej, prof. D. Grinberg - dziewiętnastowiecznymi ideologiami, prof. M. Leczyk - uwarunkowaniami położenia międzynarodowego II Rzeczypospolitej i dr hab. H. Parafianowicz - polityką zagraniczną USA w pierwszej połowie XX w.

Badania nad dziejami powszechnymi, tak w sensie poszczególnych krajów, jak też związków międzynarodowych obejmują politykę wewnętrzną i zagraniczną, oraz uwzględniają ponadto szeroko pojęte zagadnienia społeczno-gospodarcze. Prof. A. Manikowski zajmuje się wyjaśnieniem specyfiki przekształceń gospodarczych i społecznych czasów nowożytnych obserwowanych przez pryzmat działań właścicieli wielkich majątków ziemskich w siedemnastowiecznej Toskanii, prof. H. Ruciński - osadnictwem Spisza i Orawy do końca XVIII w., prof. B. Stępniewska-Holzer - zacofaniem i modernizacją obszarów pozaeuropejskich w XIX i początkach XX w., a prof. J. Kofman - zjawiskiem nacjonalizmu gospodarczego w krajach Europy Środkowo-Wschodniej w okresie międzywojennym.

O pozycji Instytutu Historii w badaniach nad dziejami powszechnymi może świadczyć fakt, iż to właśnie $z$ tego ośrodka wyszła inicjatywa napisania w ciagu paru najbliższych lat nowego, ośmiotomowego zarysu $D z i e-$ jów powszechnych dla Wydawnictwa Naukowego PWN pod redakcją naukową prof. A. Manikowskiego. W przygotowywanym wydawnictwie, które w zamiarze autorów ma odzwierciedlać poglądy tzw. średniego pokolenia historyków dwa tomy będą pisane przez profesorów z Instytutu (D. Grinberg, A. Manikowski). Dwaj inni pracownicy - prof. A. Wyczański i dr hab. C. Kuklo uczestniczą od 1989 r. w pracy zespołu badawczego w GUS-ie w Warszawie (odpowiadają za okres do 1795 r.), którego celem jest opracowanie unikalnej publikacji, nie mającej swego od powiednika w innych krajach Europy - Historia Polski w liczbach - odtwarzającej statystyczną przeszłość kraju od najstarszych, możliwych do ujęcia liczbowego, czasów aż po dzień dzisiejszy.

Osobne i szczególne miejsce zajmuja interdyscyplinarne badania prof. A. Wyczańskiego nad społeczeństwem, gospodarką i kulturą Polski ujmowane na tle wczesnonowożytnej Europy; dla epoki średniowiecza realizowane przez prof. H. Zaremską.

Historia wojskowości od połowy XVIII w. po II wojnę światową, ostatnio ze szczególnym uwzględnieniem walki zbrojnej o kształt państwa polskiego i jego granice w latach 1914-1921 uprawiana jest przede wszystkim 
za sprawą licznych studiów prof. M. Wrzoska, także prof. A. Dobrońskiego i dr. J. Snopki.

Prof. H. Konopka sporo uwagi poświęciła w ostatnich latach dziejom oświaty w Polsce powojennej, kładąc szczególny nacisk na sprawę nauczania religii $w$ polityce państwa $w$ szkołach podstawowych i średnich. Prowadzi również badania nad historią stosunków państwo - Kościół w Polsce.

Spośród innych tematów badawczych, które zdobyły uznanie środowiska wymienić należy badania demograficzne struktur rodzinnych i gospodarstw domowych społeczeństwa staropolskiego w szerokim ujęciu komparatystyki europejskiej realizowane przez dr. hab. C. Kuklę z zastosowaniem technik informatycznych. Jest on również współautorem oryginalnego systemu komputerowego pozwalającego przetwarzać informacje zaczerpnięte ze źródeł masowych XVI-XVIII w. jak księgi metrykalne, przedstatystyczne spisy ludności, księgi sądowe włącznie $\mathrm{z}$ automatyczną rekonstrukcją rodzin.

Z kolei za sprawą badań dr. J. Trynkowskiego wzbogacono też znajomość losów Polaków (w tym ich pracy i życia codziennego) zsyłanych przez carat na Syberię w XIX stuleciu.

W latach 1992-1995 pracownicy otrzymali dwa imienne granty Komitetu Badań Naukowych: dr hab. C. Kuklo - Informatyczny system rekonstrukcji rodzin, gospodarstw domowych i społeczności lokalnych w Polsce przedrozbiorowej; prof. A. Woltanowski - Grodno w XVIII wieku. Miasto i ludność. Po 1995 roku imienne granty KBN otrzymali: mgr I. Kulesza, mgr E. Bezubik oraz mgr M. Karczewski.

Wiele prac badawczych pracowników Instytutu Historii, zarówno już zakończonych, jak i nadal kontynuowanych, byłoby niemożliwe do zrealizowania bez współpracy międzynarodowej, zwłaszcza $z$ nauką zachodnią. Współpraca ta m.in. z Ecole des Hautes Etudes en Sciences Sociales w Paryżu, z Instituto di Storia Economica „F. Datini” w Prato, czy Harvard University Center for Italian Renaissance Studies, przybrała postać licznych stypendiów przede wszystkim dla młodszych pracowników, tj. asystentów i adiunktów. Dłuższe i krótsze pobyty owocowały dokształcaniem młodszej kadry tak w zakresie przejmowania najnowszej problematyki badawczej, jak i najnowszych metod. Kilkakrotnie na stypendiach w USA była dr hab. H. Parafianowicz, staże w Paryżu odbyli m.in. dr dr E. Dubas-Urwanowicz i I. Pugacewicz, dr hab. C. Kuklo, prof. J. Urwanowicz, mgr I. Kulesza, we Włoszech - dr J. Maroszek, w Izraelu - dr J. Godlewski. Z kolei profesorowie białostoccy (D. Grinberg, A. Manikowski, S. Meller) mieli możliwość głoszenia wykładów w najbardziej prestiżowych ośrodkach naukowych jak w EHESS w Paryżu, Arbor University, Emory University w Atlancie (USA). 
Współpraca międzynarodowa Instytutu Historii ma miejsce z krajami byłego ZSRR. Powstanie nowych państw za naszą granicą wschodnią ożywiło wcześniejsze kontakty $\mathrm{z}$ tamtejszymi placówkami naukowymi. Przede wszystkim nastąpiło szersze otwarcie archiwów państwowych w Wilnie, Mińsku i Grodnie czy Lwowie. Wielu pracownikom podejmującym problematykę „kresów” w różnych okresach historycznych sytuacja ta umożliwiła dotarcie do źródeł, często podstawowych, a przedtem nieznanych. Wielokrotnie na dłuższe i krótsze pobyty naukowe do Wilna, Grodna, Mińska, Kijowa, Lwowa, Czerniowiec, Kazania i innych ośrodków uniwersyteckich byłego ZSRR wyjeżdżali prof. prof. A. Dobroński, M. Gnatowski, A. Mironowicz, W. A. Serczyk, B. Stępniewska-Holzer, M. Wrzosek, dr dr A. Czapiuk, J. Maroszek, J. J. Milewski, A. Miśkiewicz, mgr mgr K. Buchowski, M. Liedke.

Wreszcie o randze białostockiego środowiska historycznego może w jakimś stopniu świadczyć fakt, że Instytut Historii tylko w ostatnich paru latach gościł znakomitych zagranicznych uczonych. Wygłaszali wykłady i odczyty oraz brali udział w dyskusjach naukowych m. in. prof. prof. Antoinette Fauve-Chamoux (EHESS), Jean-Pierre Bardet, Jean Berenger, Daniel Tollet (wszyscy z Université de Paris-Sorbonne) z Francji, Walter Leitsch z Austrii, Jakub Goldberg z Izraela, Jozef Bad'urik ze Słowacji.

Obecnie Instytut Historii współpracuje szerzej z następującymi instytucjami zagranicznymi: Ecole des Hautes Etudes en Sciences Sociales w Paryżu, Université de Paris-Sorbonne, Instituto di Storia Economica F. Datini w Prato (Włochy), Instituto di Storia Economica - Universita di Parma, Facolta di Lettere - Universita di Siena, Ecole Francaise de Roma, Harvard University - Center for Italian Renaissance Studies, University of Kansas, Indiana University, University of California w Los Angeles, George Washington University, University of Texas, Hoover Institution on War, Revolution and Peace, Virginia Community College System, Uniwersytet Karola w Pradze, Uniwersytet Komeńskiego w Bratysławie, Instytut Historii Białoruskiej Akademii Nauk w Mińsku, Wydział Historyczny Uniwersytetu Wileńskiego, Wydział Historyczny Uniwersytetu Grodzieńskiego, Wydział Historyczny Uniwersytetu w Czerniowcach, Wydział Historyczny Uniwersytetu w Mohylewie.

Instytut Historii posiada własne ogólnopolskie czasopismo naukowe „Studia Podlaskie" redagowane przez prof. M. Gnatowskiego. Od 1989 r. ukazało się 7 tomów, na łamach których obok historyków z Krakowa, Lublina, Poznania, Warszawy pisali również autorzy z Austrii, Australii, Białorusi, Francji, Izraela, i Łotwy, które zyskały już uznanie środowiska nau- 
kowego. Ponadto wydano dwa tomy innego wydawnictwa - „Białostockich Tek Historycznych" pod red. prof. M. Wrzoska.

Od 1994 r. ukazało się także 15 tomików czasopisma popularnonaukowego "Gryfita" Białostockiego Magazynu Historycznego redagowanego obecnie przez dr. W. Jarmolika, skierowanego do młodzieży szkół średnich i innych miłośników dziejów Podlasia i ziem ościennych. „Gryfita” jest również miejscem debiutów pisarskich najmłodszych pracowników Instytutu i najlepszych studentów historii.

Instytut ma bogate dalsze plany badawcze, m.in. ukierunkowane na tematy wschodnie. Trwaja dyskusje nad wyborem nowych specjalności kształcenia, również w systemie studiów podyplomowych. Jednocześnie rozpoczęto prace związane z uzyskaniem przez Instytut akredytacji kierunku studiów - historia, nadawanej przez Uniwersytecką Komisję Akredytacyjną. Jej uzyskanie będzie potwierdzeniem wysokiej jakości kształcenia w naszej placówce oraz spełnienia wysokich standardów europejskich w tym zakresie. 